\title{
DETERMINATION OF THE INVESTMENT COSTS FOR BUILDINGS RENOVATION
}

\author{
Venelin Terziev ${ }^{1}$, Svilen Stefanov ${ }^{2}$, Svetoslava Enimaneva ${ }^{3}$ \\ ${ }^{1}$ Corresponding Member of the Russian Academy of Natural History, Moscow, Russia, Prof., \\ D.Sc. (Ec.), D.Sc. (National Security), D.Sc. (Social Activities), Ph.D., National Military University, \\ Veliko Tarnovo, Bulgaria; University of Rousse, Rousse, Bulgaria, terziev@skmat.com \\ ${ }^{2}$ Prof, Ph.D., National Military University, Veliko Tarnovo, Bulgaria, sestefanov@abv.bg \\ ${ }^{3}$ Ph.D., National Military University, Veliko Tarnovo, Bulgaria, svetlush@gmail.com
}

\begin{abstract}
Theoretic and methodological aspects of making a model in general comprise the application of different scientific methods. In the current case, management of buildings condition, the appropriate methods are related to the architectural and construction features of buildings, to the energy savings gained through improvement of the outer elements (walls, floors, roofs), and to investment appraisal. The general question is how to combine these methods in order to elaborate an overall model which may be used irrespectively of the type of the building (housing, administrative, production or agricultural).
\end{abstract}

Keywords: economic efficiency, energy efficiency, investment models.

\section{INTRODUCTION}

Following the first acceptance of Energy Efficiency Law in Bulgaria (2004), a range of financial instruments became available at the market, which main purpose was to stimulate individuals and organizations in common to apply in the buildings of their own a particular method for renovation in order to gain energy savings. Negatively to the expectations, there have been observed ineffective and uncoordinated actions for improving the condition of single, small in size buildings, undertaken by economic subjects who have financial abilities. This indicated significant disadvantages and omissions in the applied legislative framework. Joining the EU, the legislation in the energy sector, and not only, had been changed in accordance to the directives of the European Council. Not a few enterprises started to generate energy from renewable resources due to its normatively regulated buy-up, which was equal to government subsidizing of this activity. But, referring to the energy consumption in buildings, there still cannot be observed positive tendencies. That has brought in question the economic efficiency of the market supplied decisions for improving the buildings condition in aim to energy savings and the relevant methods of financing, as well as the reason for their evasion from households and business organizations.

\section{DETERMINATION OF THE INVESTMENT COSTS FOR BUILDINGS RENOVATION}

In order to appraise the efficiency of a particular decision for building renovation, firstly it is necessary to determine the size of investment needed for its implementation. 
Determination of the thickness of the thermo insulation covering

Object of modelling are technically feasible variations for renovation - external and internal implementation of the thermo insulation. Construction companies in general prioritize the external implementation, but clients should also have information to what extent the internal implementation is acceptable and advisable. Each of the variations has its advantages and shortcomings.

External implementation of the thermo insulation:

advantages - during summer the outer walls warm up at a slower pace, and thus the accumulated quantity of heat in them is reduced; the façade is refreshed;

shortcomings - the thermo insulation on outer walls and roofs is aging faster due to sun heating; the costs for works implementation rise as result of scaffolding usage, safeguarding enclosures and their transport; in most cases it is normatively required a consent to renovation of all co-owners within the building, and their participation in financing as well; more financial resources are spent on improving the building interior after the thermo insulation, especially in municipal buildings as schools, kindergartens, hospitals, etc.

Internal implementation of the thermo insulation:

advantages - the physical aging of the thermo insulation is slower; the costs for its implementation are lower than the case of its external laying; each co-owner takes self-dependent decision for his/her property renovation; the loss of heat due to its accumulation in the outer walls is limited after insulation, and those in the inner walls increase;

Shortcomings - a relative size of inner space within the property is lost.

The investment costs for implementation of thermo insulation depend on physical characteristics and prices of the insulation materials chosen, as well as on the mode of laying - external or internal. The calculation of investment costs is based on the so-called analytical prices of all the construction works needed. The analytical price (calculation of components) is to be determined for a unit construction work, such as '1 m2 insulation of brick wall with XPS', and in accordance to adopted in the construction sector standards for material usage.

The algorithm of calculating the analytical price of a unit construction work is unified as a matter of principle, and does not depend on the type of construction work. The price comprises costs for materials, costs for mechanization (equipment/ tools usage), labour costs, as well as related additional costs (such as social and health insurance, safeguard garment, etc.).

Labour costs are calculated on the base of working time input for a unit of a particular construction work and the remuneration for one working hour. The necessity of adding supplementary costs evolves from legislative requirements for social and health insurance and usage of safeguarding garment and tools during the construction process, transport of the construction staff to the site, etc. It is perceived those additional costs to be calculated proportionally to the labour costs (usually $70 \%$ to $100 \%$ of the labour costs amount).

Costs for materials are calculated on the base of actual quantity of materials used (kg, m, m2, m3, etc.) and their net price for a material unit. The necessity of adding supplementary costs evolves from activities that come along with the construction, as material supply costs, warehousing, eventual overspending of materials, or damaging. By analogy, those additional costs are calculated proportionally to the actual material costs -10 to $15 \%$.

Costs for mechanization are related to the usage of different types of equipment and tools while executing the construction works for building envelope. At least usage includes activities as fitting, dismantle and provision of consumables. In case costs for mechanization are related to the usage of a specific machine, their evaluation is made through the amount of machine working hours and the net price per hour. Whenever mechanization comprises fitting and dismantle of an equipment, such as scaffolding, then costs are calculated on the base of the remuneration for the working time input for assemblage works. Supplementary costs come from activities related to equipment maintenance and eventual repair, as well as from its physical amortization. The type of equipment and intensity of its usage settle the amount of additional costs which varies from 30 to 100 per cent of the main mechanization costs (Terziev, Filipov, Enimaneva, 2017a, str.460491; Terziev, Filipov, Enimaneva, 2017b, str.56-91; Terziev, Filipov, Enimaneva, 2017c, str.92-121; Terziev, Enimanev, Enimaneva, 2017d, pp. 601-624; Terziev, Enimanev, Enimaneva, 2017e, pp. 625-651; Terziev, Enimanev, Enimaneva, 2017f, pp.653-676; Terziev, Enimanev, Enimaneva, 2017g, pp.533-573; Terziev, Enimanev, Enimaneva, 2017h, pp.574-609; Terziev, Enimaneva, Filipov, 2017i, pp. 9-27).

In compliance with the envelope implementation mode - external or internal, the investment costs needed 
for $1 \mathrm{~m} 2$ thermo insulation are to be determined as follows:

- external implementation

(1) $K_{\text {ext }}=\left(1+\mathrm{R}_{P R}\right)\left[\left(1+\mathrm{R}_{L}\right) \mathrm{L}_{\text {ext }}+\left(1+\mathrm{R}_{\mathrm{M}}\right)\left(Q_{\delta} \cdot \mathrm{P}_{\text {ins }}+M_{\text {ext }}\right)+\left(1+\mathrm{R}_{T}\right) T_{\text {ext }}\right]$

- internal implementation

(2) $\quad K_{\text {int }}=\left(1+\mathrm{R}_{P R}\right)\left[\left(1+\mathrm{R}_{L}\right) \mathrm{L}_{\text {int }}+\left(1+\mathrm{R}_{\mathrm{M}}\right)\left(Q_{\delta} \cdot \mathrm{P}_{\text {ins }}+M_{\text {int }}\right)\right]$, as

$R_{M}, R_{L}, R_{T}$ and $R_{P R}$ are rates (\%) for calculating the supplementary costs related to materials, labour, mechanization and profit;

$Q_{\delta}$ is necessary quantity $(m)$ of thermo insulation material, with definite thickness, for instance $0.01 / 0.03$ / $0.05 \mathrm{~m}$;

$\mathrm{P}_{\text {ins }}$ is price per unit thermo insulation material;

$M_{\text {ext }}, M_{\text {int }}$ is cost of all other construction materials needed for executing the construction work, such as fitting net, bolts, ground coat solution, parget coat solution, paint, respectively for external or internal implementation of the envelope;

$K_{\text {ext }}, K_{\text {int }}$ is amount of the investment costs, respectively for external or internal implementation of the building envelope.

No matter which mode will be chosen for insulation implementation - external or internal, it has to comply with two key requirements - protection from condensation appearance, and economic efficiency (Enimanev, Andonov, 2000).

Protection from condensation is actually an indicator for quality of thermo insulation implementation, and it sets the basic (minimum required in terms of quality) thickness of thermo insulation material to be used in building enveloping:

(3)

$$
\delta_{\text {ins }}=\left[\frac{t_{i}-t_{e}}{\Delta t . \alpha}-R\right] \cdot \lambda_{\text {ins }}, \text { as }
$$

$\delta_{\text {ins }}$ is the basic (minimum required) thickness of thermo insulation material $(\mathrm{m})$;

$t_{i}$ is air temperature wanted in premises $\left({ }^{\circ} \mathrm{C}\right)$;

$t_{e}$ is temperature of the atmospheric air $\left({ }^{\circ} \mathrm{C}\right)$;

$\Delta t$ is the temperature drop between the inner air temperature and the temperature at the inner surface of the wall $\left({ }^{\circ} \mathrm{C}\right)$;

$\alpha$ is coefficient for heat transfer from the inner air to the inner surface of the wall $\left(\mathrm{W} / \mathrm{m}^{2} . \mathrm{K}\right)$;

$R$ is thermal transmittance resistance of the wall before its insulating $\left(\mathrm{m}^{2} . \mathrm{K} / \mathrm{W}\right)$;

$\lambda_{\text {ins }}$ is coefficient for heat conductivity of the thermo insulation material $\left(\mathrm{W} / \mathrm{m}^{2} . \mathrm{K}\right)$.

The requirement for economic efficiency means the total costs for implementation and maintenance of the building envelope to be minimal. So this requirement is to be accomplished when the thickness of the insulation material used is optimal:

(4)

$$
\delta_{\text {ins opt }}=\sqrt{\frac{\sum_{1}^{\mathrm{n}}\left(\mathrm{t}_{\mathrm{i}}-\mathrm{t}_{\mathrm{e}}\right) \tau_{\mathrm{ij}} 10^{-3} \mathrm{P}_{\mathrm{e}} \lambda_{\text {ins }}}{\text { E.P }}}-\text { R. } \lambda_{\text {ins }} \text {, as }
$$

$\delta_{\text {ins opt }}$ is the economic efficient thickness of the thermo insulation material $(\mathrm{m})$;

$\boldsymbol{P}_{\boldsymbol{e}}$ is price per $1 \mathrm{kWh}$ energy saved in result of insulating; 
$\boldsymbol{\tau}_{\mathbf{i j}}$ is the hours of holding various temperatures of the atmospheric air during the heating season (h);

$E$ is coefficient for efficiency of the investment in energy efficient measures $\left(E=\frac{1}{T_{p b}}\right.$, as $T_{p b}$ is the term length for paying bank the investment).

Initial size of investment costs for renovation through thermo insulation

The basic (minimal) amount of investment costs for implementation of thermo insulation is determined by that thickness of the chosen insulation material, which ensures condensation not to appear in the premises. In calculating the minimal necessary investment costs, a starting point should be the major thermo physical indicator which determines the necessary thickness of the insulation material - thermal transmittance resistance. It is standardized and defined through the equation, as follows:

$$
\mathrm{R}=\frac{\mathrm{t}_{\mathrm{i}}-\mathrm{t}_{\mathrm{ei}}}{\Delta \mathrm{t} \cdot \alpha}
$$

The coefficient ${ }^{\alpha}$ is normatively defined (Nevenkin,1990), as for exterior walls $\alpha=8,7 \mathrm{~W} / \mathrm{m}^{2} . K$. The temperature drop $\Delta t$ is also defined by standards for design of thermo insulation of buildings, but it is defined only according to the temperature conditions, without taking into account the relative humidity of the inner air in premises. The humidity has considerable impact on the temperature drop. In order to determine the relation between the temperature drop and the air humidity, an evaluation is made for temperatures of the inner air from $5{ }^{\circ} \mathrm{C}$ to $30^{\circ} \mathrm{C}$ and variations of its relative humidity from $40 \%$ to $95 \%$. I-D diagram of humid air (fig. 1) is used.

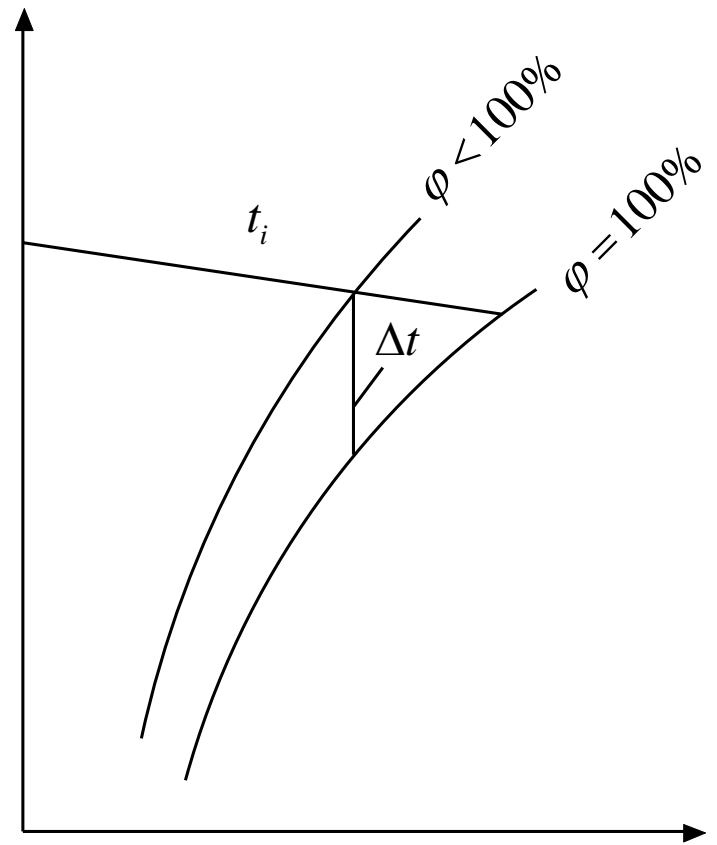

Fig.1. I-D diagram for the position of the temperature drop between the inner air temperature and the temperature of the inner side of the wall

The distribution area of the temperature drop according to changes in the relative humidity of air in premises is presented in Fig. 2. This area will determine the variation of investment costs for insulation implementation in dependence on the relative humidity of the inner air.

The subordination may be expressed as single-variable quadratic polynomial:

(6) , where

A, B and C are coefficients in the regression models (coefficients are presented for some models in table 1),

- Relative humidity of the air in the premises, \%. 
Table 1: Coefficients are presented for some models

\begin{tabular}{|c|c|c|}
\hline \multicolumn{3}{|c|}{ Regression models of the temperature drop } \\
\hline Temperature, ${ }^{0} \mathrm{C}$ & \multicolumn{1}{|c|}{ Equation } & Correlation \\
\hline 30 & $\Delta t=22.248 \varphi^{2}-54.849 \varphi+33.32$ & $R^{2}=0.9995$ \\
\hline 25 & $\Delta t=17.397 \varphi^{2}-47.724 \varphi+30.459$ & $R^{2}=0.9999$ \\
\hline 20 & $\Delta t=12.0998 \varphi^{2}-39.854 \varphi+27.584$ & $R^{2}=0.9998$ \\
\hline 15 & $\Delta t=8.468 \varphi^{2}-33.799 \varphi+25.03$ & $R^{2}=0.9998$ \\
\hline 10 & $\Delta t=7.378 \varphi^{2}-30.97 \varphi+23.31$ & $R^{2}=0.9994$ \\
\hline 5 & $\Delta t=10.55 \varphi^{2}-33.156 \varphi+22.605$ & $R^{2}=0.9974$ \\
\hline
\end{tabular}

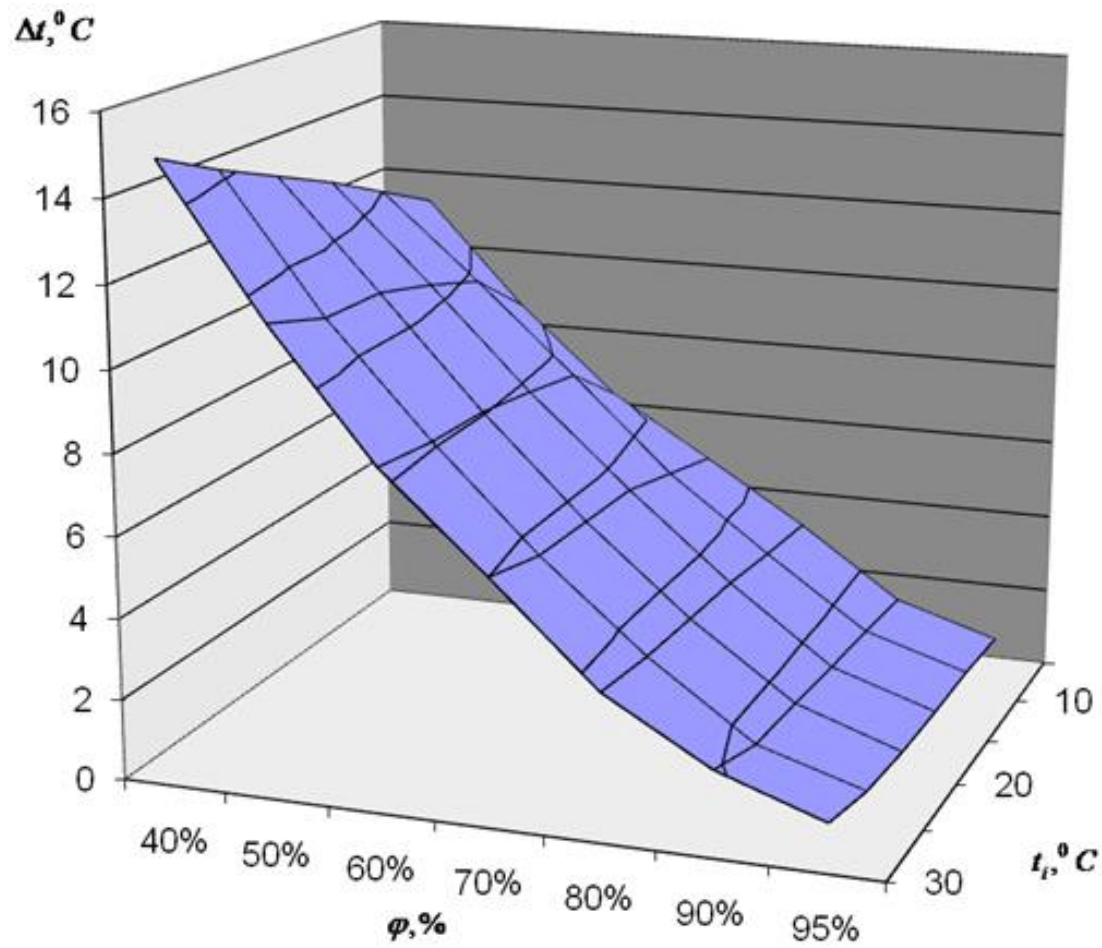

Fig.2. Area of distribution of the temperature drop in dependence on The relative humidity of inner air

In accordance to the temperature drop and taking into account the relative humidity of air in the premises, equation (5) gives calculation of the thermal transmittance resistance $R_{K \text { min , which ensures protection from }}$ condensation. These values should be accepted as minimum required and to be attained in result of thermo insulation, as

$$
\mathrm{R}_{\mathrm{Kmin}}=\frac{1}{\alpha}+\frac{1}{\alpha_{0}}+\sum_{1}^{\mathrm{n}} \frac{\delta_{\mathrm{ci}}}{\lambda_{\mathrm{ci}}}+\frac{\delta_{\text {ins min }}}{\lambda_{\text {ins }}} \text {, as }
$$

$\alpha_{0}$ is coefficient for heat transfer from the outer surface of exterior wall to the atmospheric air $\left(W / m^{2} . K\right)$;

$\delta_{c i}$ is thickness $(m)$ of each of the compound layers in walls, such as brick, ground coat, plaster coat, or panel, decorative coat, etc.; 
$\lambda_{\text {ci }}$ is coefficient of heat conductivity of the materials which the compound layers in walls are made of (W/m.K).

Formula (7) presents how to define that thickness of the thermo insulation material which ensures protection from condensation:

$$
\delta_{\text {ins min }}=\left[\mathrm{R}_{\mathrm{Kmin}}-\left(\frac{1}{\alpha}+\frac{1}{\alpha_{0}}+\sum_{1}^{\mathrm{n}} \frac{\delta_{\mathrm{ci}}}{\lambda_{\mathrm{ci}}}\right)\right] \lambda_{\mathrm{ins}} .
$$

Thus, the minimum amount of investment costs for external or internal implementation of the envelope may be defined through equations (1) and (2) calculated with the value of $\delta_{\text {ins min }}$. Respectively, the equations are to be modified as follows:

- external implementation

(9) $K_{\text {ext min }}=\left(1+\mathrm{R}_{P R}\right)\left[\left(1+\mathrm{R}_{L}\right) \mathrm{L}_{\text {ext }}+\left(1+\mathrm{R}_{\mathrm{M}}\right)\left(Q_{\text {smin }} \mathrm{P}_{\text {ins }}+M_{\text {ext }}\right)+\left(1+\mathrm{R}_{T}\right) T_{\text {ext }}\right]$

- internal implementation

$$
K_{\text {int min }}=\left(1+\mathrm{R}_{P R}\right)\left[\left(1+\mathrm{R}_{L}\right) \mathrm{L}_{\text {int }}+\left(1+\mathrm{R}_{\mathrm{M}}\right)\left(Q_{\delta \min } \mathrm{P}_{\text {ins }}+M_{\text {int }}\right)\right] \text {, as }
$$

\section{CONCLUSION}

In summary the following conclusions can be made:

In modelling the process of improving the energy efficiency of buildings through thermo insulation, a starting point has to be the choice of technically feasible variation for insulation implementation - external or internal.

The elaboration of adequate economically effective model for buildings renovation requires to take into account a range of mutually dependent factors: minimum needed amount of investment costs for the building envelope; expected quantity of energy saved in result of thermo insulation; value of the discounted cash flow calculated through the expected quantity of energy saved and current market price per unit energy source in the building; a specific ratio for the thermo insulation material chosen, which is determined by the material major insulating characteristics $(\lambda)$ and its market price ; application of roll shutters as industrial product that contributes for diminishing the energy losses through windows.

The impact that each of the identified factors has on the basic model for renovation can be expressed mathematically and thus quantitatively measured. Binding those mathematical expressions allows a complete conceptual model for buildings renovation to be constructed.

\section{REFERENCE LIST}

Terziev. V., Filipov, S., Enimaneva S. (2017a). Aprobirane na teoretichnite modeli za nivoto na energiyna efektivnost na sgradite. // Yubileyna nauchna konferentsiya "Savremenni tendentsii $v$ aviatsionnoto obuchenie”, 18 - 19 may 2017g , Natsionalen voenen universitet „Vasil Levski“ - Veliko Tarnovo gr.Dolna Mitropoliya, 2017, ISBN 978-954-713-110-1, str.460-491 (Терзиев. В., Филипов, С., Ениманева С. Апробиране на теоретичните модели за нивото на енергийна ефективност на сградите. // Юбилейна научна конференция „Съвременни тенденции в авиационното обучение”, 18 - 19 май 2017г , Национален военен университет „Васил Левски“ - Велико Търново гр.Долна Митрополия, 2017, ISBN 978-954-713-110-1, стр.460-491).

Terziev, V., Filipov, S., Enimaneva, S. (2017b). Teoretiko-metodicheski aspekti na izgrazhdaneto na modeli za podobryavane sastoyanieto na sgradniya fond (theoretic and methodological aspects of making a model for management of buildings condition). // Sbornik dokladi ot godishna universitetska nauchna konferentsiya 1-2 yuni 2017 godina, Nauchno napravlenie „Sotsialni, stopanski i nauki”, Veliko Tarnovo 2017 g., Natsionalen voenen universitet „Vasil Levski“, Veliko Tarnovo, 7, 2017, ISSN 13141937, str.56-91 (Терзиев, В., Филипов, С., Ениманева, С. Теоретико-методически аспекти на изграждането на модели за подобряване състоянието на сградния фронд (theoretic and methodological aspects of making a model for management of buildings condition). // Сборник 
доклади от годишна университетска научна конференция 1-2 юни 2017 година, Научно направление „Социални, стопански и науки”, Велико Търново 2017 г., Национален военен университет „Васил Левски“, Велико Търново, 7, 2017, ISSN 1314-1937, стр.56-91).

Terziev, V., Filipov, S., Enimaneva, S. (2017c). Faktori, opredelyashti razmera na investitsiite v povishavane na energiynata efektivnost na sgradite (Factors and a system of models for measuring their impact on the economic efficiency of investment in improving buildings condition). // Sbornik dokladi ot godishna universitetska nauchna konferentsiya 1-2 yuni 2017 godina, Nauchno napravlenie "Sotsialni, stopanski i nauki”, Veliko Tarnovo 2017 g., Natsionalen voenen universitet „Vasil Levski“, Veliko Tarnovo, 7, 2017, ISSN 1314-1937, str.92-121 (Терзиев, В., Филипов, С., Ениманева, С. Фактори, определящи размера на инвестициите в повишаване на енергийната ефективност на сградите (Factors and a system of models for measuring their impact on the economic efficiency of investment in improving buildings condition). // Сборник доклади от годишна университетска научна конференция 1-2 юни 2017 година, Научно направление „Социални, стопански и науки”, Велико Търново 2017 г., Национален военен университет „Васил Левски“, Велико Търново, 7, 2017, ISSN 1314-1937, стр.92-121).

Terziev, V., Enimanev, K., Enimaneva, S. (2017d). Factors and a system of models for measuring their impact on the economic efficiency of investment in improving buildings condition (Фактори, определящи размера на инвестициите в повишаване на енергийната ефективност на сградите). // Twelfth international scientific conference Knowledge without borders, 31.3-2.4.2017, Vrnjacka Banja, Serbia, Institute of Knowledge Management, Skopje 16, 2017, N 2, ISSN 1857-923X, pp. 601624.

Terziev, V., Enimanev, K., Enimaneva, S. (2017e). Testing the system of theoretic models (Апробиране на теоретичните модели за нивото на енергийна ефективност на сградите). // Twelfth international scientific conference Knowledge without borders, 31.3-2.4.2017, Vrnjacka Banja, Serbia, Institute of Knowledge Management, Skopje 16, 2017, N 2, ISSN 1857-923X, pp.625-651.

Terziev, V., Enimanev, K., Enimaneva, S. (2017f). Theoretic and methodological aspects of making a model for management of buildings condition (Теоретико - методически аспекти на изграждането на модели за подобряване състоянието на сградния фонд). // Twelfth international scientific conference Knowledge without borders, 31.3-2.4.2017, Vrnjacka Banja, Serbia, Institute of Knowledge Management, Skopje 16, 2017, N 2, ISSN 1857-923X, pp.653-676.

Terziev, V., Enimanev, K., Enimaneva, S. (2017g), Theoretic and methodological aspects of making a model for management of buildings condition. // Proceedings of the VII International Academic Congress "Fundamental and Applied Studies in EU and CIS Countries" (United Kingdom, Cambridge, England, 26-28 February 2017), Cambridge University Press, 7, 2017, ISBN: 978-0-875-83597-4, pp.533-573, Source Normalized Impact per Paper (SNIP): 5.192 SCImago Journal Rank (SJR): 5.186 Impact factor: 7.549 .

Terziev, V., Enimanev, K., Enimaneva, S. (2017h). Factors and a system of models for measuring their impact on the economic efficiency of investment in improving buildings condition. // Proceedings of the VII International Academic Congress „Fundamental and Applied Studies in EU and CIS Countries” (United Kingdom, Cambridge, England, 26-28 February 2017), Cambridge University Press, 7, 2017, ISBN: 978-0-875-83597-4, pp.574-609, Source Normalized Impact per Paper (SNIP): 5.192 SCImago Journal Rank (SJR): 5.186 Impact factor: 7.549.

Terziev, V., Enimaneva, S., Filipov, S. (2017i). Economic efficiency and investment implementation in energy saving projects. // Journal of Innovations and Sustainability, Innovations and Sustainability Academy, 3, 2017, N 3, pp. 9-27, ISSN 2367-8127 (CD-ROM), ISSN 2367-8151 (on-line). 